\title{
The influence of field strength and initial water content on electroosmotic dewatering of cement mortar slurries in the presence of SDS
}

\section{Citation for published version (APA):}

Kuin, A. J., Ogrinc, H. J. A., \& Stein, H. N. (1987). The influence of field strength and initial water content on electroosmotic dewatering of cement mortar slurries in the presence of SDS. Colloids and Surfaces, 27(1-3), 6580. https://doi.org/10.1016/0166-6622(87)80134-8

DOI:

10.1016/0166-6622(87)80134-8

Document status and date:

Published: 01/01/1987

\section{Document Version:}

Publisher's PDF, also known as Version of Record (includes final page, issue and volume numbers)

\section{Please check the document version of this publication:}

- A submitted manuscript is the version of the article upon submission and before peer-review. There can be important differences between the submitted version and the official published version of record. People interested in the research are advised to contact the author for the final version of the publication, or visit the $\mathrm{DOI}$ to the publisher's website.

- The final author version and the galley proof are versions of the publication after peer review.

- The final published version features the final layout of the paper including the volume, issue and page numbers.

Link to publication

\footnotetext{
General rights

- You may freely distribute the URL identifying the publication in the public portal. follow below link for the End User Agreement:

www.tue.nl/taverne

\section{Take down policy}

If you believe that this document breaches copyright please contact us at:

openaccess@tue.nl

providing details and we will investigate your claim.
}

Copyright and moral rights for the publications made accessible in the public portal are retained by the authors and/or other copyright owners and it is a condition of accessing publications that users recognise and abide by the legal requirements associated with these rights.

- Users may download and print one copy of any publication from the public portal for the purpose of private study or research.

- You may not further distribute the material or use it for any profit-making activity or commercial gain

If the publication is distributed under the terms of Article $25 \mathrm{fa}$ of the Dutch Copyright Act, indicated by the "Taverne" license above, please 


\title{
The Influence of Field Strength and Initial Water Content on Electroosmotic Dewatering of Cement Mortar Slurries in the Presence of SDS
}

\author{
A.J. KUIN*, H.J.A. OGRINC** and H.N. STEIN \\ Eindhoven University of Technology, Postbox 513, $5600 \mathrm{MB}$ Eindhoven (The Netherlands)
}

(Received 31 December 1986; accepted in final form 17 March 1987)

\begin{abstract}
The influence of the applied field strength and initial water content on electroosmotic dewatering is studied.

In the curves describing the water content as a function of time during electroosmosis, a point is found at which the slope of the curves abruptly decreases. This point can be explained by the occurrence of menisci.

The efficiency of the electroosmotic dewatering is calculated as the mass of water removed per unit of electrical work input. It decreases with time in the course of one dewatering experiment, and with increasing electrical field strength. Nevertheless, it is substantially (about 100 times) greater than the efficiencies achieved in previous studies.

From the difference between the electrical conductivities in the direction of the current, and in a direction perpendicular to the current, canal formation is apparent.
\end{abstract}

\section{INTRODUCTION}

The dewatering and drying of slurries has been a technological problem for a long time $[1,2]$. It is usually performed by evaporating the water by heating, but this is a rather energy consuming method. A method which has so far received little attention and can be less energy consuming is electroosmotic dewatering (subsequently abbreviated as EOD).

EOD is a method in which an electrical potential difference is applied across a slurry. This results in water transport which, if taking place in the correct direction, facilitates the removal of water until too much of it has been replaced by air and the process stops.

Very little fundamental literature on EOD exists, but many patents have been granted (see e.g. Refs [3-8]). These patents mostly concern electrode

\footnotetext{
*Present address: Unilever Research Laboratories, Vlaardingen, The Netherlands.
}

**Present address: Océ van der Grinten, Venlo, The Netherlands. 
TABLE 1

Characterization of the size and shape distribution of the sand and portland B fractions

\begin{tabular}{llcllll}
\hline $\begin{array}{l}\text { Sieve } \\
\text { fraction }\end{array}$ & $\begin{array}{l}\text { Averaging } \\
\text { proc. }\end{array}$ & $\begin{array}{l}\text { Length } \\
(\mu \mathrm{m})\end{array}$ & $\begin{array}{l}\text { Thickness } \\
(\mu \mathrm{m})\end{array}$ & Length/thickness & $\begin{array}{l}\text { Eq. sphere } \\
\text { diameter }\end{array}$ & $\begin{array}{l}\text { Eq. sphere } \\
\text { volume }\end{array}$ \\
\hline $250-315$ & number & 279 & 201 & 1.42 & 244 & 0.0989 \\
& volume & 333 & 252 & 1.37 & 300 & 0.1701 \\
$600-1000$ & number & 893 & 653 & 1.38 & 776 & 0.2920 \\
& volume & 1036 & 782 & 1.35 & 950 & 0.5480 \\
Portland & number & 5.64 & 3.37 & 1.68 & 4.49 & $0.911 \times 19^{-7}$ \\
B. & volume & 9.34 & 5.55 & 1.72 & 7.38 & $3.210 \times 10^{-7}$ \\
\hline
\end{tabular}

constructions. Apparently hardly any research has been done on the fundamental processes influencing EOD. This may be one of the reasons that it has been difficult to use EOD successfully [9-14]. This lack of success is mainly due to a lack of understanding of the fundamental processes involved. For example, it has been shown by Wittmann et al. [15] that dewatering by electroosmosis is very difficult if one does not reduce the capillary forces.

In this paper the influence of the applied field strength and initial water content on EOD of cement mortar slurries is studied. In order to reduce the surface tension, a surfactant (sodium dodecyl sulphate, SDS) was added to the mixing water.

\section{EXPERIMENTAL}

\subsection{Materials}

Sand: The systems to be dewatered were composed from sieve fractions $600-1000 \mu \mathrm{m}$ and $250-315 \mu \mathrm{m}$ which were prepared by dry sieving from Maas sand (from Braat Bouwstoffen N.V.) These sieve fractions were characterized as described in Refs $[17,18]$; the results are shown in Table 1. Coarse monodisperse sand (average particle diameter $776 \mu \mathrm{m}$, polydispersity $=1.01$ ) was employed to support the electrodes.

Cement: Portland B, from ENCI, Maastricht.

Water: double distilled water was used.

Sodium dodecyl sulphate: from $\mathrm{BDH}$.

\subsection{Apparatus}

The electroosmotic dewatering experiments were performed on slurries which were poured into a thermostated, slightly conical vessel A (see Fig. 1). The vessel was conical in order to allow the cement mortar to be removed more easily. It had been silanized with dimethyldichlorosilane from $\mathrm{BDH}$ Chemicals 


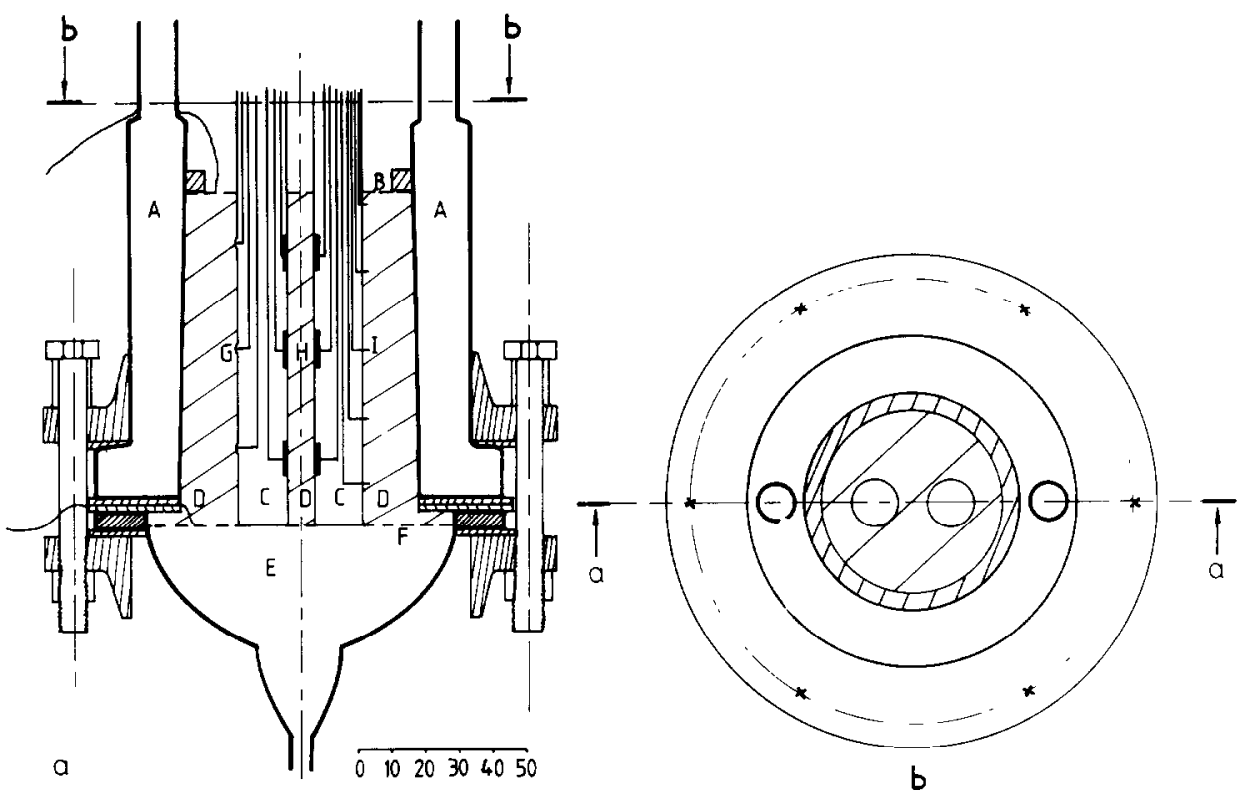

Fig. 1. EOD apparatus with sensor. (a) Side cross section; (b) top cross section. (A) Thermostated vessel, (B) upper electrode, (C) sensor, (D) sample, (E) sand filter supporting the bottom electrode, (F) bottom electrode, (G) thermocouple, (H) conductivity cell, (I) potential sensor.

(prod. No. 28197) [16] in hexane in order to fully cover its glass surface with $\mathrm{CH}_{3}$ groups. This prevented the mortar from sticking to the surface. Together with the upper electrode (B), a sensor (C) was inserted into the paste. This sensor consisted of a $\mathrm{U}$-shaped tube carrying thermocouples and electrodes at its outer surface, for measuring local temperature, potentials and electrical conductivities at predetermined places in the paste. Radial conductance was measured at three places via the conductivity cells $\mathrm{H}$.

The local temperature was measured at three places at the sensor surface ( $G$ ) and the local potential with electrodes I at five places. The conductivity cells and working electrodes $B$ and $F$ consisted of unblackened platinum. The bottom electrode was supported by coarse monodisperse sand ( $F$ ). This secured sufficient support for the electrode and prevented the cement mortar from flowing through the meshes of the bottom electrode. The filter sand was coarse enough to have a negligible flow resistance as compared to the resistance of the slurry.

\subsection{Procedure}

Slurries were prepared by mixing by hand and deposited in the apparatus under horizontal vibration by means of an A.S. Vibromixer ( $40 \mathrm{~W})$. The sand was kept wet so as to avoid air getting in between the filter and the slurry. The 


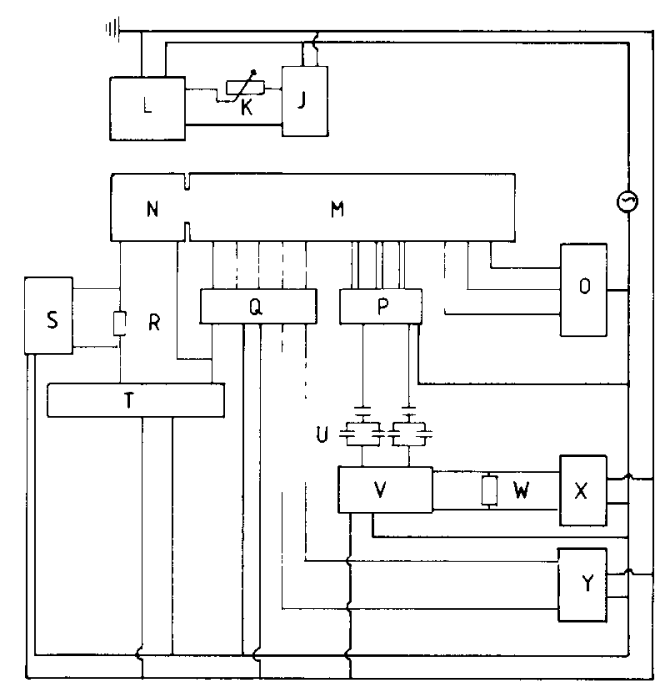

Fig. 2. The electronic circuit of the EOD apparatus. For a description see the text.

measuring sensor was inserted together with the upper electrode, and vibration was continued for $5 \mathrm{~min}$.

After each slurry had been prepared, the electrodes and sensor ( $M$ ) were attached to the electronic circuit (Fig. 2), and the slurry $\mathrm{N}$ was left to drain under gravity to consolidate to a packed bed. This usually took about $10 \mathrm{~min}$. Then the electroosmosis was started by switching on a Delta electronic SCR 300-8 power supply ( $\mathrm{T}$ ) with a preset voltage.

For 90 min 13 signals were continuously recorded:

(a) The mass of water removed was measured with a Sartorius automatic balance 1400 MP 7-2 (L) which via a variable resistance (K) transferred a signal to a Kipp \& Zonen BD 40 recorder (J).

(b) The direct current flowing between the electrodes was obtained by inserting a resistance of $5 \Omega(\mathrm{R})$ into the circuit and measuring the potential drop with a similar recorder $(\mathrm{S})$ as above.

(c) The radial conductances were measured at $2.2,5.3$ and $8.0 \mathrm{~cm}$ above the bottom electrode. Their values were obtained with a radiometer conductivity bridge (V). All three signals were recorded on a Kipp \& Zonen BD 40 recorder (X) with a parallel resistance of $568 \Omega$ (W) which received from each conductivity cell a signal for a period of $30 \mathrm{~s}$ before it was switched to the next cell by an electronic device (P). A set of ceramic capacitors of $6 \mu \mathrm{F}$ (U) was inserted between the conductivity meter and the conductivity cells in order to separate the direct current from the alternating current between the electrodes making up the conductivity cells.

(d) The temperature at the sensor surface was measured at distances of 2.2 , 
5.3 and $8.3 \mathrm{~cm}$ above the bottom electrode. The local temperature was registered via Philips thermocoax 2AB35 thermocouples. The signals from the thermocouples were recorded on a Philips PM 8235 multipoint recorder $(0)$.

(e) The local potential was measured at distances of 1.2, 3.2, 5.2, 7.2 and 9.2 $\mathrm{cm}$ from the bottom electrode, which was used as a reference electrode. All five potentials were recorded on a Servogor 120 recorder (Y). Each signal was recorded for about $30 \mathrm{~s}$. Then the next signal was recorded, etc. The signals were separated by the electronic device $\mathbf{Q}$.

Two kinds of samples were used. They differ in the weight ratio of liquid to cement, the so-called $W / C$ ratio. One set of samples had an initial $W / C=0.80$ and one had an initial $W / C=0.47$.

The samples with $W / C=0.80$ consisted of $125 \mathrm{~g}$ Portland B, $100 \mathrm{~g} 0.05 \mathrm{M}$ SDS, $200 \mathrm{~g}$ sand sieve fraction $600-1000 \mu \mathrm{m}$ and $175 \mathrm{~g}$ sand of sieve fraction $250-315 \mu \mathrm{m}$. The length of the beds was $9 \pm 0.5 \mathrm{~cm}$. The cross-sectional area was $36.3 \mathrm{~cm}^{2}$. The density of the sand was taken as $2.7 \mathrm{~g} \mathrm{~cm}^{-3}$ and that of Portland B as $3.15 \mathrm{~g} \mathrm{~cm}^{-3}$ according to Neville [19]. The total volume was $327 \mathrm{~cm}^{3}$.

From the densities of Portland $\mathrm{B}$ and sand and the respective weights added to the slurry, the volume of solid phase could be computed. The hydrodynamic porosity was then computed as the volume of non-solid divided by the total volume, i.e. as the relative transportable volume. This hydrodynamic porosity was 0.45 .

If the density of the liquid was taken to be $1 \mathrm{~g} \mathrm{~cm}^{-3}$ then the amount of air enclosed was $48 \mathrm{~cm}^{3}$, which is about $14 \% \mathrm{v} / \mathrm{v}$. The electrical porosity can then be computed as the ratio of the liquid volume to the total volume, i.e. the relative conducting volume of the slurry. This electrical porosity was 0.3 .

The samples with an initial $W / C=0.47$ consisted of $70 \mathrm{~g} 0.05 \mathrm{M}$ SDS, $240 \mathrm{~g}$ sand of sieve fraction $600-1000 \mu \mathrm{m}, 210 \mathrm{~g}$ sand of sieve fraction $250-315 \mu \mathrm{m}$ and $150 \mathrm{~g}$ Portland $\mathrm{B}$.

The lengths of these beds were $10.5 \mathrm{~cm}$. The total volume was $381 \mathrm{~cm}^{3}$, so that the amount of air was $97 \mathrm{~cm}^{3}$ which is $25 \%$ of the total volume. The hydrodynamic porosity was 0.44 and the electrical porosity was 0.18 .

\section{RESULTS AND DISCUSSION}

The amount of liquid displaced as a function of time is shown in Fig. 3 for one experiment.

If the dewatering process is quasi-stationary, the amount of water removed by EOD is given by:

$G_{\mathrm{eo}}=\frac{\tilde{m} \epsilon \zeta}{\eta} \int_{0}^{t} \frac{I(t)}{\Lambda(t)} \mathrm{d} t$ 


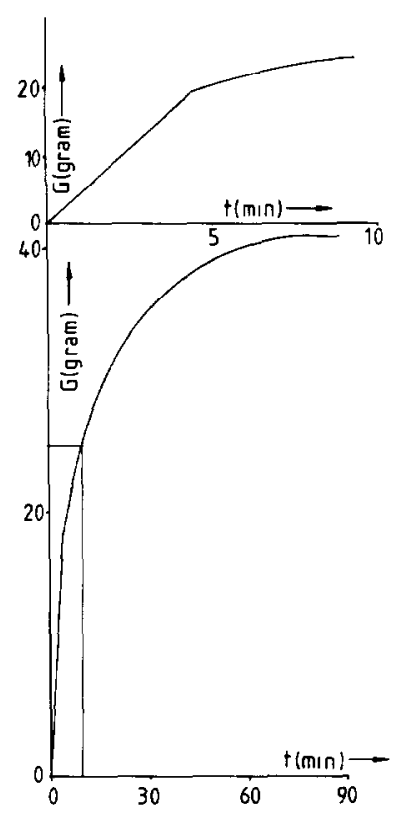

Fig. 3. The amount of liquid dewatered as a function of time. The enclosed part of the bottom figure is enlarged in the upper part.

which is the integrated form of von Smoluchowski's equation [20-23] multiplied by the density $\tilde{m}$. This equation is more or less equivalent to the one postulated by Kobayashi et al. [24-26] for the behaviour of compressible slurries during EOD at constant current.

$A(t)$ and $I(t)$ are the specific conductance of the solution and the electrical current as a function of time, respectively. $\epsilon$ is the permittivity, $\zeta$ the zeta potential and $\eta$ the dynamic viscosity.

The conductivity can be written as [20]

$$
A(t)=\frac{I(t) F}{\Delta V}
$$

where $\Delta V$ is the applied potential difference and $F$ is the structure resistance coefficient (subsequent abbreviated as SRC) defined by Dukhin and Derjaguin [20], which includes the effective cross-sectional area of the pore, the effective length of the electric field lines and the electrical porosity.

Substitution of Eqn (2) into Eqn (1) and integration gives

$G_{\mathrm{eo}}-\frac{\check{m} \epsilon \zeta \Delta V t}{\eta F}$

This equation predicts that if the zeta potential and the SRC are time-inde- 


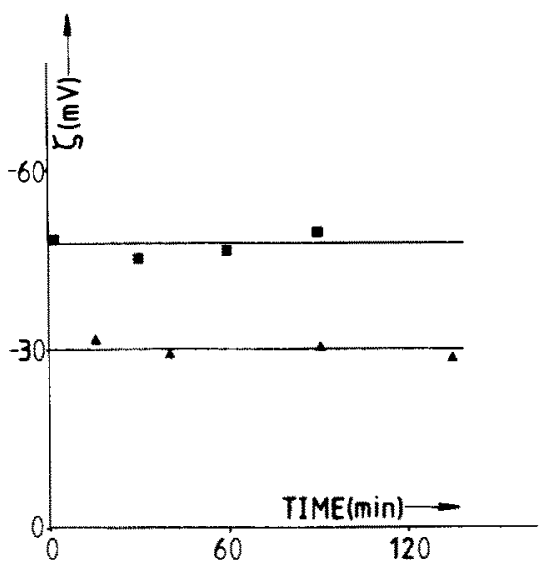

Fig. 4. The zeta potential as a function of time. (D) Sand, in $0.05 \mathrm{MSDS}$ and sat. $\left(\mathrm{Ca}(\mathrm{OH})_{2}\right.$. (A) Portland $\mathrm{B}$, in $0.05 \mathrm{M}$ SDS and sat. $\mathrm{Ca}(\mathrm{OH})_{2}$.

pendent, the amount of water removed by EOD would be proportional to the time. This is clearly not the case.

The deviation from linearity can be caused by: (a) capillary forces which are due to the introduction of menisci during EOD for which no allowance was made in Eqn (1), (b) variation of the zeta potential with time, and (c) time dependence of the SRC.

Inclusion of capillary forces gives a progressively decreasing dewatered amount such as one would expect (Fig. 3 ) if it is assumed that first the largest pores are dewatered and then subsequently smaller ones.

The zeta potential of sand and Portland B did not vary with time (Fig. 4) within the periods of our experiments. The zeta potential was determined by sedimentation of Portland B in water-free butanol, taking off the fraction lower than $2 \mu \mathrm{m}$, drying and measuring the zeta potential by electrophoresis with a Rank Brothers Mark 2 apparatus. It should be remarked, however, that the electrophoresis experiments were performed in excess surfactant solution, and therefore are not strictly indicative of the in situ situation in the paste.

The SRC does change with time as liquid is replaced by air. Equation (3) then becomes:

$G_{\mathrm{eo}}=\frac{\tilde{m} \epsilon \zeta \Delta V}{\eta} \int_{0}^{t} \frac{\mathrm{d} t}{F(t)}$

It can be concluded that both (a) and (c) can explain the dewatering results. The electrical current reaches a plateau value (Fig. 5). This suggests that either there remains a liquid film on the particles after EOD which still con- 

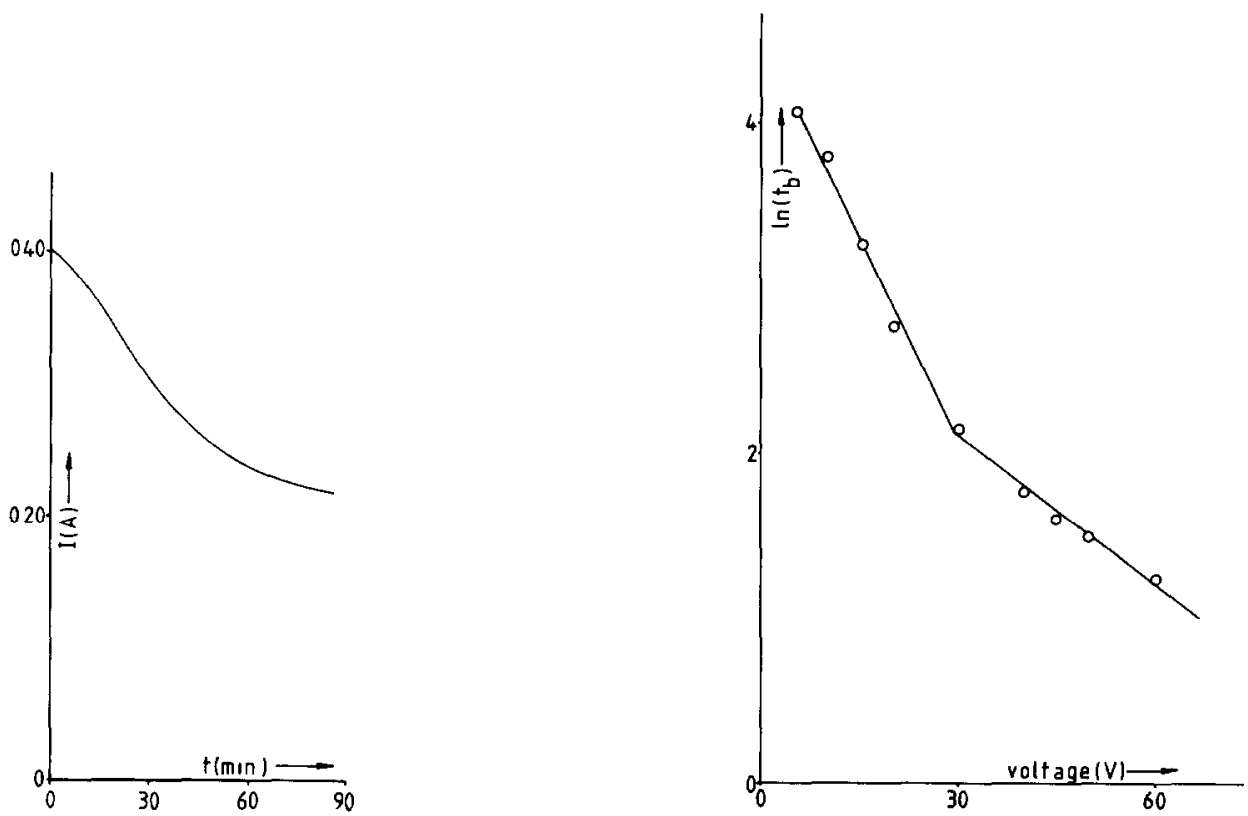

Fig. 5. The axial current as a function of time.

Fig. 6. The logarithm of the time in minutes after which the bending point occurs as a function of the applied potential. Initial $W / C=0.80$.

ducts a current or that the smallest pores cannot be dewatered due to capillary suction.

A change in slope was found in the EOD-time curve (Fig. 3), which could be approximated by a bending point. Such a bending point has been reported by Lockhart [27] and by Yukawa et al. [25]. This suggests that the occurrence of such a bending point is independent of the material involved and is a characteristic of the EOD process. If the time at which the bending point $t_{\mathrm{b}}$ occurs is plotted logarithmically against the applied voltage for an initial $W / C$ ratio of 0.80 , the curve can be approximated by two straight lines (Fig. 6).

The points from 5 to $30 \mathrm{~V}$ can be fitted with the equation:

$\ln \left(t_{\mathrm{b}}\right)=4.49-0.0802 \mathrm{~V}$

with a linear regression correlation coefficient of -0.994 , where $t_{\mathrm{b}}$ is in minutes and $V$ is in volts.

The points from 30 to $60 \mathrm{~V}$ can be fitted with the equation:

$\ln \left(t_{\mathrm{b}}\right)=3.00-0.0299 \mathrm{~V}$

with a correlation coefficient of -0.993 . No such curve was constructed for an initial $W / C$ ratio of 0.47 as the spread in the measurements was too large. 

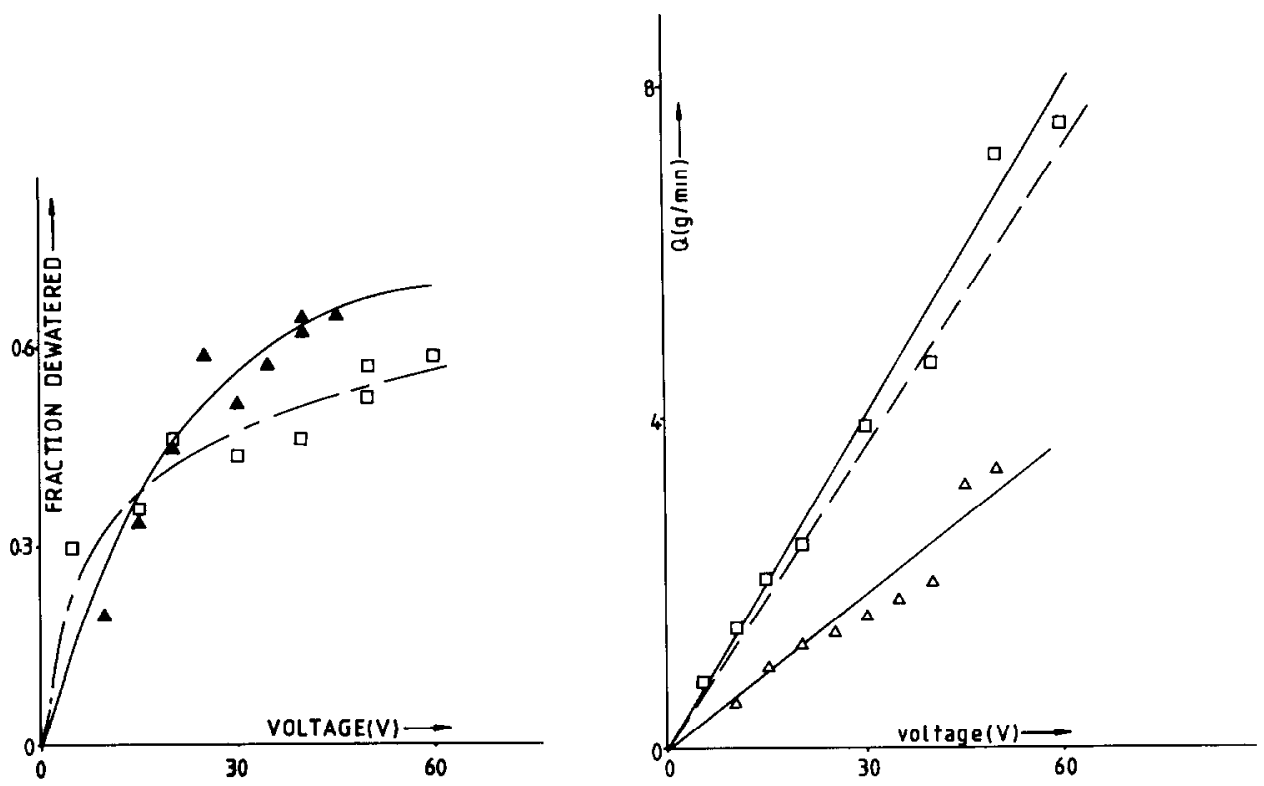

Fig. 7. The fraction dewatered after $90 \mathrm{~min}$ as a function of the voltage at an initial $W / C$ ratio of $0.80(\square)$ and $0.47(\Delta)$.

Fig. 8. The initial flow rate as a function of the applied potential at an initial $W / C$ ratio of 0.80 ( $\square$ ) and $0.47(\triangle)$. ( - - ) The theoretical curve calculated for $W / C=0.80$ from data at $W / C=0.47$ (see text).

In Fig. 7 the percentage of the initial solution content dewatered after 90 min is shown for both initial $W / C$ ratios as a function of the applied voltage difference. In both cases the fraction dewatered increases with the applied potential. From the figure it is clear that a larger fraction is removed if the initial water content is lower.

The initial dewatering velocity as shown in Fig. 8 also differs for both initial $W / C$ ratios. In both cases it is a linear function of the applied voltage difference. The difference is mainly due to a different length of the two types of beds and a difference in electrical porosity.

To test this the equation of Neale [28]:

$\frac{I}{\Delta P}=-\frac{\epsilon \zeta}{\eta} A \tau p$

for the streaming current of porous beds is combined with the following relation from irreversible thermodynamics [29]:

$\left(\frac{I}{\Delta P}\right)_{\Delta V=0}=\left(\frac{J_{v}}{E}\right)_{\Delta P=0}$ 
to give

$J_{v}=-\frac{\epsilon \zeta}{\eta} A \frac{\Delta V}{l} p \tau$

$\tau$ is the tortuosity, and $p$ the electrical porosity.

In these equations $\Delta P$ is the pressure difference across the porous beds, $E$ the electrical field strength and $A$ the cross-sectional area. Thus this equation is based on the assumption that the pores in the porous medium may be treated as tortuous cylinders. Assuming that the tortuosity, the zeta potential and the viscosity are in both cases equal, then

$J_{0.8}=\frac{p_{0.80} l_{0.47}}{p_{0.47} l_{0.80}} J_{0.47}$

If $J_{0.80}$ is computed from $J_{0.47}$ when the appropriate values for the electrical porosity and the length are substituted, the broken curve in Fig. 8 is obtained.

The predicted curve is very close to the measured one, which indicates that the lower initial velocity at lower $W / C$ ratio is mainly caused by air entrapment which influences the electrical porosity.

The differences still left after correcting for differences in porosity are probably due to uncertainties in the hydrostatic pressures across the bed and measuring errors in the porosity and length of the beds. The linear behaviour suggests that the first part of EOD is quasi-stationary. The bending point in Fig. 3 can then be understood as being due to the influence of capillary forces due to the introduction of menisci.

A time dependence of the SRC cannot explain the bending point, as any conceivable change in the SRC occurs progressively rather than abruptly. It should also be noted that the change in slope occurs more gradually at low dewatering field strengths or low $W / C$ ratios than at high field strength and $W / C$ ratio, which suggests a more gradual occurrence of menisci and a larger saturation gradient in the former cases. The saturation gradient is, according to Schubert [30], large if the saturation decreases over a large part of the bed.

The anisotropy defined as the ratio of the axial conductivity of the bed to the radial conductivity of the bed:

$a=\frac{\Lambda^{\mathrm{ax}}}{\Lambda^{\mathrm{rad}}}$

is shown in Fig. 9.

The axial conductivity is obtained by inserting $F=l / A$ with $l$ the length of the bed and $A$ the cross section.

The radial conductivity is obtained as 


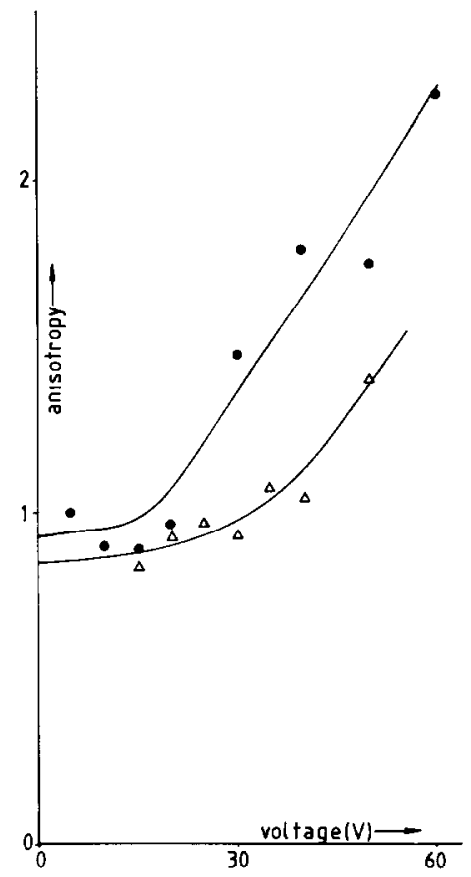

Fig. 9. The anisotropy after $90 \mathrm{~min}$ as a function of the voltage at an initial $W / C$ ratio of 0.80 and $0.47(\Delta)$.

$$
\Lambda^{\mathrm{rad}}=\frac{1}{\sum \frac{1}{\Lambda_{i}}}
$$

where $A_{i}$ are the measured conductivities as described in section 2 .

This anisotropy is explained by canal formation in the direction of liquid flow.

As can be seen from the anisotropy results, canal formation is more pronounced at $W / C=0.80$. Figure 9 also shows that at the start of the experiments the anisotropy is slightly smaller than unity. This is probably due to a slight layer formation when the slurry is inserted. For both initial $W / C$ ratios the anisotropy increases with increasing voltage difference, due to a larger initial dewatering velocity. At initial $W / C=0.80$, canal formation hardly occurs below $30 \mathrm{~V}$.

The electrical current as a function of time and voltage difference is shown for initial $W / C=0.80$ in Fig. 10 and for initial $W / C=0.47$ in Fig. 11. Figure 10 shows that the dependence is initially linear, but finally a plateau is formed. Thus at $t=0$ the resistance is equal for all samples, but after 90 min the resistance increases with the field strength, probably due to greater initial water 

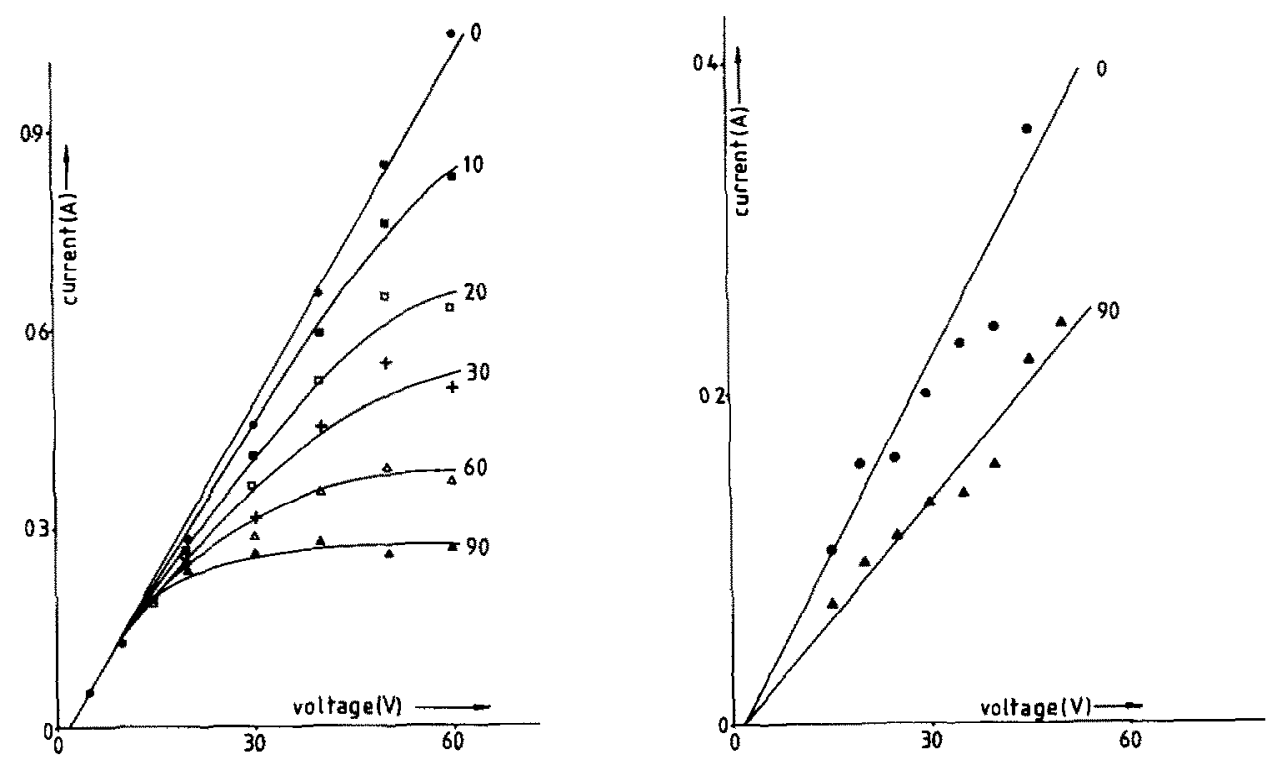

Fig. 10. The current as a function of the applied voltage with the time (in minutes) as parameter. Initial $W / C$ ratio $=0.80$.

Fig. 11. The current as a function of the applied voltage with the time (in minutes) as parameter. Initial $W / C$ ratio $=0.47$.

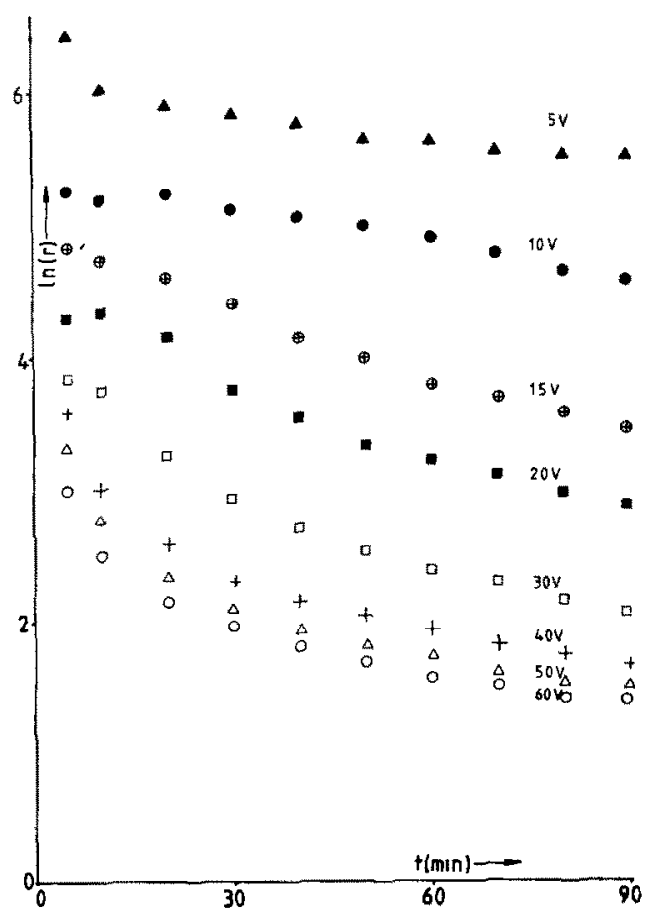

Fig. 12. The logarithmic efficiency as a function of the time and applied potential. The initial $W / C$ ratio is 0.80 , the efficiency is in gram per watt second. 

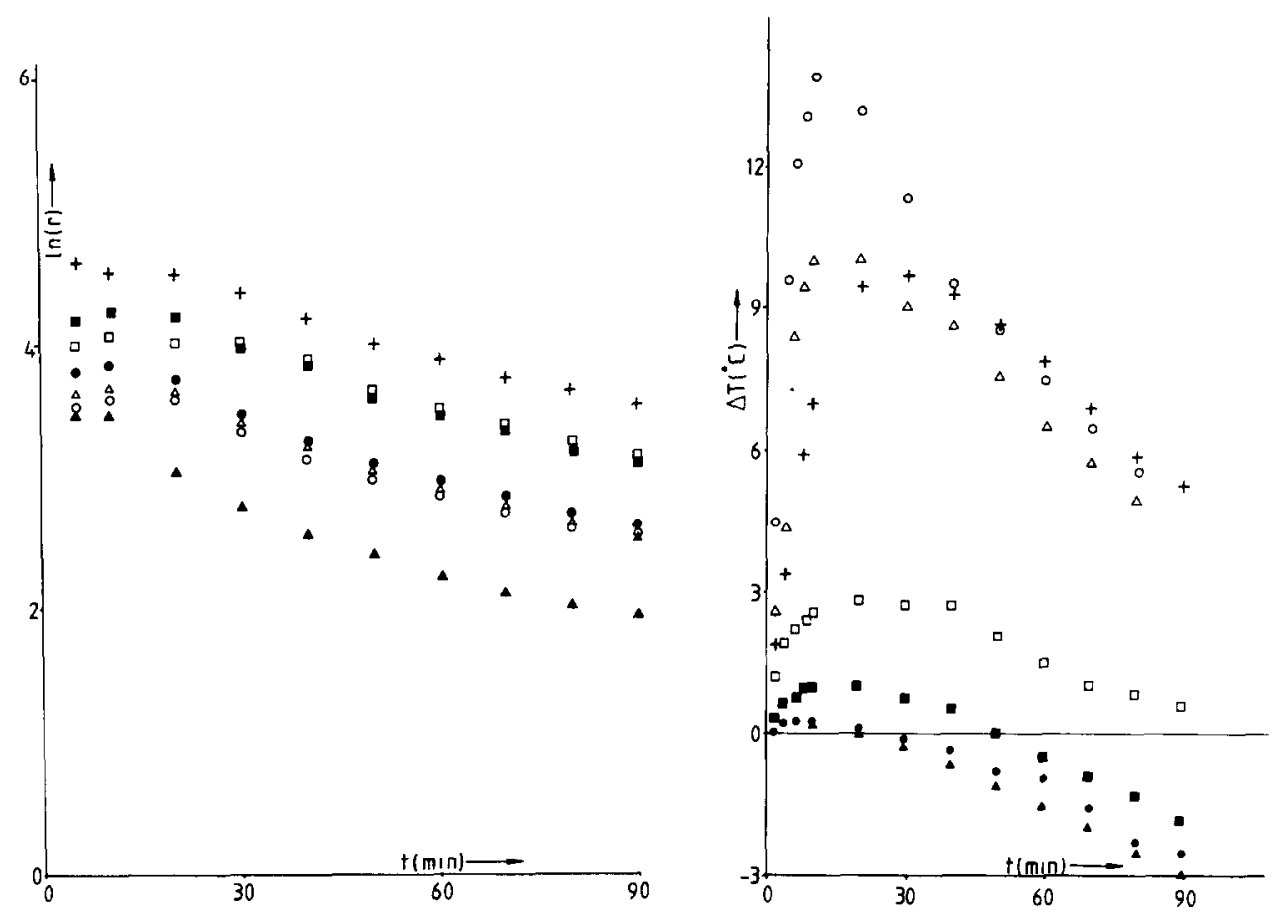

Fig. 13. The logarithmic efficiency as a function of the time and potential at an initial $W / C$ ratio of 0.47 . The efficiency is in gram per watt second. (+) $15 \mathrm{~V} ;(\square) 20 \mathrm{~V}$; ( $\square) 25 \mathrm{~V}$; (O) $30 \mathrm{~V}$; ( $\triangle$ ) $35 \mathrm{~V}$; (O) $40 \mathrm{~V} ;(\Delta) 45 \mathrm{~V}$.

Fig. 14. The temperature difference $\left(T_{\text {wall }}=25^{\circ} \mathrm{C}\right)$ as a function of the time and potential. Initial $W / C$ ratio is 0.80 . (O) $60 \mathrm{~V} ;(\Delta) 50 \mathrm{~V} ;(+) 40 \mathrm{~V} ;(\square) 30 \mathrm{~V} ;(\square) 20 \mathrm{~V} ;(\bullet) 10 \mathrm{~V} ;(\Delta) 5 \mathrm{~V}$

removal at larger field strengths. In addition, at high field strengths canal formation is more pronounced. For an initial value $W / C=0.47$ the current-voltage dependence is less time-dependent than at $W / C=0.80$.

The current is still a linear function of the applied voltage difference after $90 \mathrm{~min}$ and the decrease in current is much less. This corresponds with a more gradual dewatering at $W / C=0.47$ than at $W / C=0.80$. This is caused by a larger saturation gradient. In addition, canal formation is less pronounced.

The efficiency of EOD can be defined as

$$
r=\frac{G_{\mathrm{eo}}(t)}{V \int_{0}^{t} I(t) \mathrm{d} t}
$$

which is the mass of water removed per unit of electrical work input. $r$ as a function of voltage and time is shown in Fig. 12 for an initial $W / C$ ratio of 0.80 

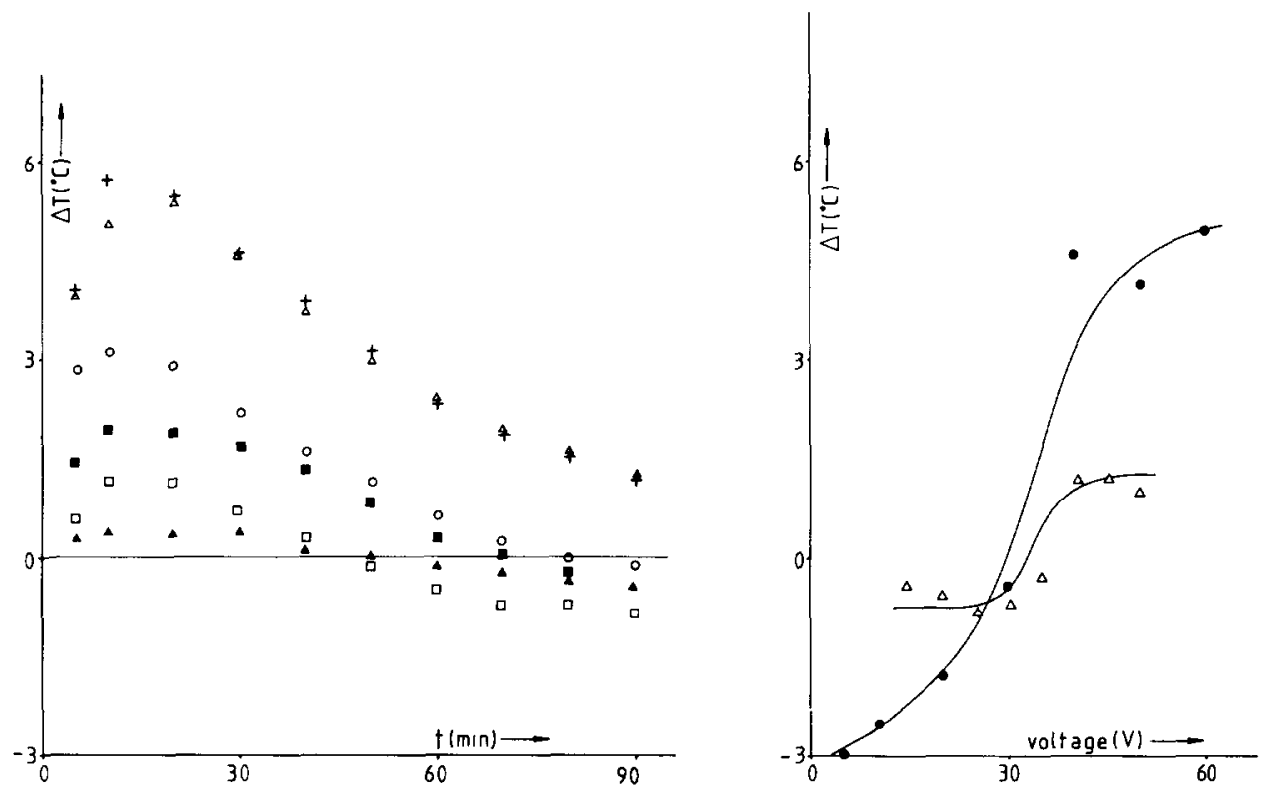

Fig. 15. The temperature difference $\left(T_{\text {wall }}=25^{\circ} \mathrm{C}\right)$ as a function of the time and applied potential. Initial $W / C$ ratio $=0.47$. (+) $45 \mathrm{~V} ;(\Delta) 40 \mathrm{~V} ;(\mathrm{O}) 35 \mathrm{~V} ;(\mathbb{D}) 30 \mathrm{~V} ;(\square) 20 \mathrm{~V} ;(\Delta) 15 \mathrm{~V}$

Fig. 16. The temperature difference $\left(T_{\text {wall }}=25^{\circ} \mathrm{C}\right)$ after $90 \mathrm{~min}$ as a function of the applied bed potential at an initial $W / C$ ratio of $0.80(\bullet)$ and $0.47(\Delta)$.

and in Fig. 13 for an initial $W / C$ ratio of 0.47 . In general, $r$ as obtained in the present investigation is at least 100 times greater than efficiency achieved in other studies $[13,31,32]$.

The efficiency decreases as time proceeds and is also lower if the potential difference is raised or the $W / C$ ratio is increased.

The average temperature difference at the sensor surface relative to the initial temperature as a function of time and applied voltage is shown in Fig. 14 for initial $W / C=0.80$ and in Fig. 15 for initial $W / C=0.47$. In the beginning the samples are heated by ohmic heat generation until a quasi-stationary state is obtained. Then the temperature decreases due to a decrease in current.

Initially the temperature is not $25^{\circ} \mathrm{C}$ but $29-31^{\circ} \mathrm{C}$, due to chemical heat generation which is caused by the reaction of cement minerals, especially tricalcium aluminate, with the surfactant solution [33-36].

Between 30 and $40 \mathrm{~V}$ there is a very large increase in heat generation. This is also reflected in Fig. 16 where the average temperature after 90 min is shown. At $W / C=0.80$ the effect is much more pronounced than at $W / C=0.47$, due to a lower air content.

A typical example of the dimensionless potential as a function of height and time for various applied voltage differences is shown in Fig. 17. Clearly the 


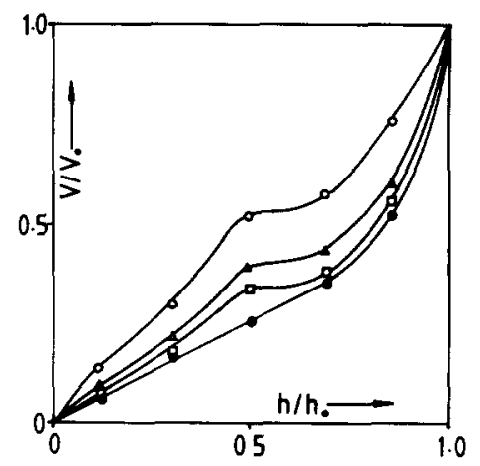

Fig. 17. The relative potential as a function of the relative position in the bed and the time. $(O)$ $0 \mathrm{~min}$; $(\triangle) 30 \mathrm{~min}$; ( $\square$ ) $60 \mathrm{~min}$; (๑) $90 \mathrm{~min}$.

potential drop is largest in the upper part of the bed. This is even more pronounced with increasing time. This behaviour corresponds to the findings of Yoshida et al. [37]. It can also be seen that an irregularity is smoothed out as time proceeds. Irregularities are mainly due to irregular packing on the scale of the potential measuring electrodes, which are about $0.25 \mathrm{~mm}^{2}$ in cross section.

\section{CONCLUSIONS}

An abrupt change in slope is found in the EOD curve (amount of water removed as a function of time). This abrupt change in slope can be ascribed to the introduction of menisci into the porous medium during the dewatering.

The initial dewatering rate increases with initial $W / C$ ratio due to a smaller air content of the porous bed. This causes increased canal formation with a concomitant smaller saturation gradient in the bed. This in turn creates a larger time-averaged electrical resistance and causes the effect of capillary forces to become noticeable at an earlier stage. The efficiency of the EOD process in the present experiments is much better than in previous studies.

\section{ACKNOWLEDGEMENTS}

We would like to thank the "Stichting Technische Wetenschappen" for their financial support and Doris Jakubekova and Hans Kusters for performing the electrophoresis measurements.

\section{REFERENCES}

1 R.J. Keey, Drying: Principles and Practice, Pergamon Press, New York, 1972.

2 A.S. Mujumdar, Drying '84, Springer-Verlag, Berlin, 1984.

3 C.A. Kunkle, W.F. Abercombie and C.J. Akins, US patent 4110189 (1978). 
4 J.G. Sunderland and C.L. Cacicedo, British patent 1414564 (1975).

5 M.P. Freeman, French patent 2354802 (1978).

6 J. Greyson and H.H. Rogers, U.S. patent 3664940 (1972).

7 M.P. Freeman, Dutch patent 7706125 (1978).

8 B. Schwerin, German patent 131932 (1915).

9 E.J. Sunderland, Dewatering Sewage Sludge by Electroosmosis: Part 1, Basic Studies, PB Report 276411 National Technical Information Service, Springfield, VA 22161, 1976.

10 G. Ellis and J.C. Sunderland, Dewatering Sewage Sludge by Electroosmosis: Part 2, Scale Up Data, PB Report 276412 National Technical Information Service, Springfield, VA 22161, 1977.

11 J. Greyson and H.H. Rogers, U.S. patent 3,664,940 (1972).

12 C.A. Kunkle, W.F. Abercrombre and C.J. Akins, U.S. patent 4,110,189 (1978).

13 R.M. Sprute and D.J. Kelsh, U.S. Bur. Mines Rep. Invest., 76 (1976) RI 8197 (68 p.), Chem. Abstr., 86, 145290e.

14 J. Grayson and H.H. Rogers, Adv. Water Pollut. Res., 71 (1969) 2-26.

15 F.H. Wittmann, S. Madra and C. Ferraris, Chantiers 13 (1982) 21.

16 S.V. Kao, L.W. Nielsen and C.T. Hill, J. Colloid Interface Sci., 53 (1975) 358.

17 A.J. Kuin and H.N. Stein, J. Colloid Interface Sci., 108 (1985) 37.

18 A.J. Kuin, Thesis, Eindhoven University of Technology, 1986.

19 A.M. Neville, Properties of Concrete, 2nd edn, Pitman, London, 1977.

20 S.S. Dukhin and B.V. Derjaguin, in E. Matijević (Ed.), Surface and Colloid Science, Vol. 7, Plenum, New York, 1974.

21 M. Von Smoluchovski, Bull. Akad. Sci. Bracovié classe Sci. Math. Natur 1 (1903) 182.

22 R.J. Hunter, Zetapotential in Colloid Science, Academic Press, New York, 1981.

23 D.J. Shaw, Introduction to Colloid and Surface Chemistry, 2nd edn, Butterworks, London, 1979.

24 K. Kobyashi, M. Hakoda, Y. Hosoda, M. Iwata and H. Yukawa, J. Chem. Eng. Jpn., 12 (1979) 492.

25 H. Yukawa, H. Yoshida, K. Kobayashi and M. Hakoda, J. Chem. Eng. Jpn., 9 (1976) 402.

26 H. Yukawa, K. Kobayashi, H. Yoshida and M. Iwata, Prog. Filtr. Sep., 79 (1978) 83.

27 N.L. Lockhart, Colloids Surfaces, 6 (1983) 229.

28 S.M. Neale and R.H. Peters, Trans. Faraday Soc., 42 (1946) 478.

29 P. Mazur and J.Th.G. Overbeek, Rec. Trav. Chim. Pays Bas, 70 (1951) 83.

30 H. Schubert, Kapillarität in porösen Feststofsystemen, Springer Verlag, Berlin, 1982.

31 J.G. Sunderland, Elec. Counc. Res. Cen. Capenhurst ECRC/N - 973 (1976).

32 N.L. Lockhart and R.E. Stickland, Powder Technol., 40 (1984) 215.

33 J.G.M. De Jong, Thesis, Eindhoven University of Technology, 1968.

34 J.G.M. De Jong, H.N. Stein and J.M. Stevels, J. Appl. Chem., 19 (1969) 25.

35 H.N. Stein, J. Appl. Chem., 15 (1965) 314.

36 W.H. Costanje, H.N. Stein and J.N. Stevels, Cem. Concr. Res., 3 (1973) 791.

37 H. Yoshida, T. Shinkawa and H. Yukawa, J. Chem. Eng. Jpn., 18 (1985) 337. 